RESENHA

\title{
SORIANO DÍAZ, Ramón; ALARCÓN CABRERA, Carlos; MORA MOLINA, Juan (Directores). Diccionario crítico de los derechos humanos. Huelva (España): Universidad Internacio- nal de Andalucia, Sede Iberoamericana, 2000. 315 p.
}

José Geraldo de Sousa Junior*

A disposição para o exame deste belo projeto, a edição de um dicionário crítico de direitos humanos, não advém apenas da concordância com as razões da iniciativa. De fato, estou de acordo com os diretores e coordenadores da edição, quanto aos motivos e à oportunidade da publicação da obra: "o interesse social que suscita esta classe de direitos pela relevância do bens jurídicos protegidos, o extraordinário desenvolvimento normativo e institucional, ao nível interno-estatal e internacional, na defesa e promoção dos direitos humanos, e as constantes controvérsias entre os estudiosos e na opinião pública sobre seu significado e alcance, que são causa do caráter antagônico de seu exercício, de sua ineficácia na prática social e da fácil instrumentalização de que são objeto pelas esferas de poder".

A disposição vem, principalmente, da mobilização comum em torno de um projeto que leva em conta razões teóricas que sustentem aqueles motivos, enquanto programa continuado de uma instituição, a Universidade Internacional de Andalucia, em sua Sede Iberoamericana de la Rábida, programaticamente vocacionada para o diálogo aberto com a sociedade e para a produção de análises esclarecedoras acerca de idéias controvertidas.

Em torno do mosteiro medieval, ao abrigo do qual Colombo encontrou as condições que lhe permitiram organizar a expedição de 1492, abrindo-

Diretor da Faculdade de Direito da UnB, Coordenador do Projeto "O Direito Achado na Rua", Membro do Núcleo de Estudos para a Paz e os Direitos Humanos da UnB. 
se ao mar, ao largo de Palos de la Frontera, o belo campus internacional de La Rábida, recebe hoje estudantes de toda a América para estudos pós-graduados.

Em 1999, a convite do Programa de Mestrado em Pluralismo Jurídico e Direitos Humanos, dirigido àquela altura por Joaquin Herrera Flores e David Sanchez Rubio, ambos da Universidade de Sevilha, desenvolvi um dos módulos do curso, como professor visitante, recolhendo dessa atmosfera acadêmica a solidariedade intelectual compartilhada de preocupações com os direitos humanos.

$\mathrm{Na}$ antiga biblioteca, resultante do ambiente profícuo de reflexão, monografias especializadas, manuais e obras gerais sobre o tema, dão a medida dos assuntos que circulam por impulso das interpelações de alunos a seus professores. $E$ agora, a esses textos, vem agregar-se esta nova publicação, "sintética e acessível, na qual possamos encontrar, cômoda e rapidamente, noções gerais sobre um tema concreto dentro da ampla matéria dos direitos humanos". Esta, efetivamente, a intenção dos organizadores deste Dicionário Crítico dos Direitos Humanos. "Dicionário - eles dizem - porque contém o conceito e a problemática geral de uma série de vozes relevantes da matéria. Crítico, porque a exposição não consiste numa mera descrição, mas numa ordenação comum de orientações teóricas controvertidas sobre as vozes selecionadas, desenvolvida com espírito crítico".

O arranjo, com efeito, menos que adensar tematicamente o conteúdo da obra, opta por acentuar a pluralidade de participações, com um elenco altamente representativo de autores, cuja expressão científica, é reconhecidamente apta a traduzir o amplo debate contemporâneo que se desenvolve doutrinariamente, em torno ao tema dos direitos humanos, com aportes interdisciplinares próprios a essa matéria - história, fundamentos, positivação, teoria geral. Assim, a presente edição se desdobra em quatro partes por meio das quais procura apreender a complexidade temática dos direitos humanos: introdução, valores jurídicos, teoria geral e tipologia de direitos.

Na primeira parte, desenvolvendo noções introdutórias, estão presentes com seus respectivos temas, Norberto Bobbio, El fundamento de los derechos humanos; Francisco J. Laporta, El concepto de los derechos humanos; Antonio E. Pérez Luño, La universalidad de los derechos humanos; Gregório Peces-Barba, Los derechos humanos y los deberes 
fundamentales; Javier de Lucas, Multiculturalismo y derechos humanos; Francisco J. Ansuátegui Roig, La historia de los derechos humanos; Vittorio Frosini, Los derechos humanos en la era tecnológica.

É conhecida a exortação de Bobbio dirigida ao fato de que a questão atual relativa aos direitos humanos já não é a de fundamentá-los, mas de garanti-los. Ou seja, o problema deixa de ser filosófico para ser político e, em última análise, jurídico. Vê-se que a preocupação com os fundamentos ainda é relevante e a ela se dedica o melhor do pensamento hispânico contemporâneo, sem dúvida instigado pelos debates que se seguiram à promulgação de sua Constituição inspirada nos protocolos de Moncloa, roteiro para uma Espanha que se redemocratizava.

Na segunda parte, tendo como roteiro o tema dos valores jurídicos, comparecem Eusébio Fernández, Dignidad y derechos humanos; Alfonso Ruiz Miguel, Libertad y derechos humanos; Carlos Alarcón Cabrera, Igualdad y derechos humanos; Ernesto Vidal Gil, Solidaridad y derechos humanos; Juan A. García Amado, Legitimidad y derechos humanos.

A aproximação ao debate neste contexto, ou seja, numa conjuntura de redemocratização, se bem insira os valores, como os próprios temas o indicam, numa experiência européia ocidental, o faz como estratégia de reconstrução emancipatória que inscreve os direitos humanos, conforme salienta Boaventura de Sousa Santos, como elementaridade da linguagem da política progressista.

$\mathrm{Na}$ terceira parte ordenam-se os temas relativos à teoria geral dos direitos humanos: Derechos humanos y estado de derecho, de Elias Díaz; Derechos humanos y democracia, de Pablo A. Bulcourf; Derechos humanos y derechos subjetivos, de Juan R. de Páramo Argüelles; Los limites de los derechos humanos, de Rafael de Asís Roig; La protección estatal de los derechos humanos, de Ana Salado Osuna; Garantismo y derechos humanos, de Marina Gascón; e Seguridad pública y derechos humanos, de Marcelo Sain.

O eixo temático, orientado pelo garantismo, remete à exigência de conversão da linguagem dos direitos em políticas públicas para a sua realização, o que consiste em transformar conceitos em práticas efetivas.

A partir da consideração do pluralismo jurídico, e de um modelo de interlegalidades que nele se fundamenta, Boaventura de Sousa Santos aponta para o que designa porosidades de diferentes ordens jurídicas que obrigam a constantes transições e transgressões. É neste contexto 
que o sociólogo português repõe o tema dos direitos humanos referidos às práticas sociais emancipatórias, nas quais as transgressões concretas são sempre, diz ele, produto de uma negociação e de um juízo político.

Para Boaventura, a reciprocidade é o critério geral de uma política democrática emancipatória, enquanto a forma e os meios de negociação deverão ser privilegiadamente os direitos humanos como expressão avançada de lutas pela reciprocidade.

Por isso se diz que a história dos direitos humanos não é a história das declarações que os enunciam, não é a história das instituições, nem sequer a história das idéias filosóficas e dos valores. É, sim, a história dessas lutas sociais, enquanto ensaio de positivação da liberdade conscientizada e conquistada no processo de criação dos direitos que realizam as aspirações à reciprocidade.

No quarto e último bloco, abre-se espaço a um catálogo de direitos humanos controvertidos. Desse elenco figuram Juan J. Mora Molina, El derecho a la vida; Luis García-San Miguel, El derecho a la intimidad; Modesto Saavedra López, El derecho a la libertad de expresión; Benito de Castro Cid, Los derechos sociales; Fernando León Jiménez, Los derechos ecológicos; José I. Lacasta Zabalza, El derecho de autodeterminación; e Ramón L. Soriano Díaz, Los derechos de las minorías.

Os temas, na sua atualidade crítica, abrem ensejo a pelo menos duas ordens de considerações. De um lado, uma designação de protagonismos, gerando concepções e uma pluralidade de discursos que reclamam diálogo intercultural designado por diferentes particularismos. São os movimentos sociais, as ONGs, são atores sociais constituídos em grupos de interesses elaborando agendas não diretamente referidas aos padrões hegemonistas da tradição institucional ocidental. De outro, a constatação de que esse processo, aludindo a práticas plurais emancipatórias, aponta para uma realidade prática, segundo a qual, na sua aplicação, os direitos humanos não são sociologicamente, como é assente na cultura ocidental, ao menos filosoficamente, universais e indivisíveis.

No seu conjunto, os textos do Dicionário não dão respostas conclusivas para estas questões, mas abrem, sem dúvida, perspectivas para que elas sejam enfrentadas. São temas que, por sua qualificação, transcendem as culturas e interpelam o que nelas há de comum, enquanto expressão de humanidade, algo mais pertinente que a ilusão corrente de universalismo. 